\title{
Motility and Functional State of the Membrane of Caprine Capacitated Spermatozoa under Different Chemical Agents
}

\author{
Alejandra Soberano Martínez ${ }^{1 *}$, José Herrera Camacho ${ }^{2}$, José Candelario Segura Correa ${ }^{3}$ \\ ${ }^{1}$ Centro Multidisciplinario de Estudios en Biotecnología, Facultad de Medicina Veterinaria y Zootecnia, \\ Universidad Michoacana de San Nicolás de Hidalgo, Morelia, Mexico \\ ${ }^{2}$ Instituto de Investigaciones Agropecuarias y Forestales, Universidad Michoacana de San Nicolás de Hidalgo, Posta Zootecnia, \\ Tarímbaro, México \\ ${ }^{3}$ Campus Ciencias Biológicas y Agropecuarias, Universidad Autónoma de Yucatán, Mérida, México \\ Email: *morula_2@hotmail.com
}

Received May 24, 2012; revised June 30, 2012; accepted August 20, 2012

\begin{abstract}
The objective of this study was to test the use of a commercial extender (Triladyl) as a diluent in caprine semen refrigerated at $15^{\circ} \mathrm{C}$, using caffeine (CF), heparin (HP), synthetic oviductal fluid (SOF) andtriladyl (TRY) as capacitating chemical agents at different times. Twenty ejaculates of caprine semen were collected using an artificial vagina. The ejaculates were diluted and refrigerated by three days. Evaluated the progressive motility (PM) and the functional state of the sperm plasma membrane trough fluorescent CTC staining, counting 200 spermatic cells (non-capacitated spermatozoa NCS, capacitated CS and reacting spermatozoa REA) of caprine in two capacitating agents: CAF and HEP; one culture medium: SOF and a commercial extender: TRY at 60,120, 180 and 240 min of incubation, during 24, 48 and 72 hs. PM was high under TRY, and CS was high under the HEP treatment. TRY could be an alternative to capacitate caprine spermatozoa, keeping PM for a longer time than HEP or CAF.
\end{abstract}

Keywords: Spermatozoa; Capacitation; Caprine; Chemical Agents

\section{Introduction}

Artificial insemination (AI) is probably the reproductive technology most widely used, because it is simple and the highest benefit: Cost ratio when tested bucks are used for reproduction [1]. Semen from tested bucks could be used fresh, freeze or frozen. However, fresh semen must be used inmediately after its collection, because motility and viability of the spermatozoa is reduced in a short time. However, frozen semen could be maintained longer than $48 \mathrm{hs}$ [2], providing a greater flexibility of their use in AI programs. frozen semen could be carry from the animal breeding center or a given ranch to the desire one [3]. Preservation of ovine semen kept at $15^{\circ} \mathrm{C}$ [4] caprinesemen at $5^{\circ} \mathrm{C}-21^{\circ} \mathrm{C}[5]$ and canine semen [6] has been notified. However, it has been found that the production of reactive oxygen species (ROS) occurs mainly during the cooling period at $5^{\circ} \mathrm{C}$ [7].

In this context, semen has been diluted in Tris base extenders using as cryoprotector agent non-penetrant lipoproteins of yolk egg and milk proteins because both act against the osmotic effects of the cooling process, pro-

${ }^{*}$ Corresponding author. ducing that the hypertonic medium cause the exit of water of the cells, increasing dehydration and reducing the possibility of intracellular crystal ice formation. However, even though this diluent length the lifetime of the spermatozoa and allow the sperm capacitation [8], this does not happen during the cryopreservation process of the caprine spermatozoa, because the interaction of the egg yolk [9] and descreamed milk [10] with the seminal plasma produce a set of nocive reactions for the spermatozoa [11], and irreversible damages in the structure and function of the membranes during the froze and defroze processes [12], which limits the use of AI in caprines.

The in vivo sperm capacitation occurs during migration in the reproductive tract of the female, whereas in vitro capacitation requires the exposition of fresh or freeze semen to specific capacitating agents [13]. The beginning of this process implies the remotion of cholesterol and probably other sterols from the plasmatic membrane of the spermatozoa, changes in the membrane, flux and redistribution of the proteins modulacion in the intracellular ion concentration $\left(\mathrm{Ca}^{2+}, \mathrm{HCO}_{3}{ }^{-}, \mathrm{K}^{+}\right.$and $\left.\mathrm{Na}^{+}\right)$, hyperpolarization of the plasmatic membrane associated with $\mathrm{K}^{+}$flux, $\mathrm{pH}$ increase and increase of phosphoryla- 
tion of the protein tyrosine [14].

Many methods have been applied to measure the changes that occur in the membrane, during the in vitro capacitation process. The most common method used is chlortetracycline staining (CTC) [15]. This fluorescent antibiotic binds to the membrane linking cations, specially $\mathrm{Ca}^{+2}$ and then shows an increase of fluorescence on the segments of themembrane where these cations acumulate. CTC staining has demonstrated to interact with spermatozoa of different species of mammals, that present different fluorescent patterns on the spermatozoa head, which are though to express different stages of the capacitation process [16].

In vivo the oviductal fluid of the reproductive tract of the female is used as cholesterol-acceptor because is rich in albumins and high density lipoproteins (HDL), capable of withdrawing cholesterol from the membrane of the spermatozoa [17]. Similarly, the pass through the reproductive tract cause that the spermatozoa get ride of the seminal plasma keeping only those proteins or descapacitating factors (muco-polysaccharides and proteins) that cover the spermatic surface [18], which are removed in the oviductal crypts [19] and by progesterone receptors ones initiated the capacitation process [20]. In vitro studies, glycosaminoglycans (GAGs) have been identified as efficient inductors of the spermatozoa capacitation. This group of carbohydrates (polysaccharides) formed by repetitive units of disaccharides include the heparin, heparin sulphate, chondroitin sulphate, keratan sulphate and hyaluronic acid [21]. GAGs promote the capacitation binding and removing the proteins of the seminal plasma fixed by adsortion to the plasma membrane of the spermatozoa and inhibin the capacitation [22]. Heparin has been the most potent inductor of capacitation, because it attaches to the spermatozoa through union proteins situated in the cell membrane, driving to the affluence of $\mathrm{Ca}^{+2}$, which increases the synthesis of AMPc and consequentely produce the protein phosphorylation [23]. Caffeine is an alkaloid compose of the metilxantin group used in vitro as capacitating agent because it inhibit the phosphodisterasa nucleotide which is responsible of the degradation of AMPc; inducing an increase in its concentration [24]. This has conducted to find new ways to improve the spermatozoa capacitation results. Bergqvist et al., [16] have pointed out the use of oviductal fluid collected in vivo, as spermatozoa capacitation medium for bovines. The use of this medium based on synthetic oviductal fluid (SOF) of ovine has not been used in caprines. The use of only the extender triladyl on caprine frozen semen and spermatozoa capacitation with caffeine, heparin, SOF and extender triladyl have also not been evaluated.

The objective of this study was to test the use of a commercial extender (Triladyl) as a diluent in caprine semen refrigerated at $15^{\circ} \mathrm{C}$, using caffeine $(\mathrm{CF})$, heparin (HP), synthetic oviductal fluid (SOF) andtriladyl (TRY) as capacitating chemical agents at different times.

\section{Materials and Methods}

Twenty ejaculates from a buck (Saanen) were collected using an artificial vagina. The semen was evaluated in terms of its micro and macroscopic characteristics and thereafter diluted 9:1 in a commercial base TRIS (Triladyl, Minitüb, Tiefenbach, Germany) extender and refrigerated at $15^{\circ} \mathrm{C}$. In order to evaluate the spermatozoa capacitation of the cool semen under different conditions, the experimental protocol was carried out during three consecutive days.

Semen samples $(3 \mathrm{ml})$ diluted in TRIS were divided in four aliquots, which were incubated at $37^{\circ} \mathrm{C}$ by $15 \mathrm{~min}$. Samples were swim-up three times consecutively. Semen was centrifuged at $750 \mathrm{rpm}$ by $5 \mathrm{~min}$ at room temperature. The semen fluid was decanted and reposed twice with equal volume of $\mathrm{mDM}$ medium and homogenerized gently. In the third wash the pill was incubated with $\mathrm{mDM}$ for 45 min to allow to up and select the spermatozoa with greater movility [25].

The supernatant was separated and placed in independent vials to get the different treatments of the study: Treat 1) upper fraction $+\mathrm{mDM}(\mathrm{Vol} / \mathrm{vol})+$ Caffeine (concentration $5 \mathrm{mM}$; CA); Treat 2) upper fraction + $\mathrm{mDM}(\mathrm{Vol} / \mathrm{vol})+$ Heparin $(50 \mu \mathrm{g} / \mathrm{ml}$; HE); Treat 3) upper fraction + synthetic oviductal fluid (SOF; Vol/vol; and Treat 4) upper fraction + Triladyl (TR; Vol/vol).

Evaluation of the functional state of the spermatic membrane: It was done trough fluorescent CTC staining, counting 200 spermatic cells. The evaluation of the functional state of the membrane and PM of the spermatozoa was carried out in $150 \mu \mathrm{l}$ of each treatment sample at 60 , 120, 180 and $240 \mathrm{~min}$. At all times the treatments stayed in incubation at $37^{\circ} \mathrm{C}$. The protocol was repeated $24 \mathrm{hs}$ (day 2) and 48 hs (day 3) with diluted semen and refrigerated in Triladyl.

The functional state of the membrane was classified according to staining portion in the following categories: a) Non-capacited spermatozoa, with uniform fluorescencein the head and intact acrosome; b) Capacitated spermatozoa, with fluorescence concentrated in the acrosomal region, a band without fluorescence in the postacrosomal region and the presence of intact acrosomes; c) Spermatozoa with acrosomal reaction, without fluorescence in the head, except by a thin band in the equatorial region [26].

Statistical analysis: The effect of chemical agent caffeine (CF), heparin (HP), synthetic oviductal fluid (SOF) and triladyl (TRY) extender, culture time $(60,120,180$ and $240 \mathrm{~min}$ ), day of evaluation (1,2 and 3) and simple 
interactions among them on progressive motility (PM), non-capacitated spermatozoa (NCS), capacitated spermatozoa capacitated (CS) and reacting spermatozoa (REA) was tested. Data were analyzed using the general linear model procedure of SAS [27].

\section{Results}

The statistical analysis showed effects of treatment $(\mathrm{P}>$ $0.0001)$, day $(\mathrm{P}>0.0001)$ and culture time $(\mathrm{P}>0.0001)$. However, there was no effect of the treatment ${ }^{*}$ day $(\mathrm{P}>$ $0.476)$ and treatment ${ }^{*}$ time interaction $(\mathrm{P}>0.995)$.

Treatment effect: PM, CS, NCS and REA were affected by treatment. A greater PM and NCS spermatozoa was observed for TRY and SOF treatments $(\mathrm{P}<0.01)$, respectively (Table 1). CS was better for HEP and CAF; whereas better REA was found for CAF.

Time effect: PM was greatest at $120 \mathrm{~min}$ and $\mathrm{CS}$ at $240 \mathrm{~min}$ as compared with other culture times (Table 2). No significant difference was found with respect to REA.

Effect of day (Storage time): Evaluation day had a significant effect on PM and CS; as day of evaluation increased PM decreased but CS increased (Table 3).

Table 1. Effect of treatment on progressive motility and functional state of the plasmatic membrane of caprine spermatozoa.

\begin{tabular}{ccccccc}
\hline Variable (\%) & Caffeine & Heparin & SOF & Triladyl & SE & P-value \\
\hline PM & $29.2^{\mathrm{a}}$ & $34.8^{\mathrm{a}}$ & $59.9^{\mathrm{b}}$ & $65.9^{\mathrm{b}}$ & 1.67 & 0.0001 \\
$\mathrm{CS}$ & $59.5^{\mathrm{ab}}$ & $63.2^{\mathrm{a}}$ & $55.7^{\mathrm{bc}}$ & $54.2^{\mathrm{c}}$ & 0.95 & 0.0011 \\
NCS & $31.2^{\mathrm{a}}$ & $29.2^{\mathrm{a}}$ & $37.1^{\mathrm{b}}$ & $37.8^{\mathrm{b}}$ & 1.09 & 0.0002 \\
REA & $9.3^{\mathrm{a}}$ & $7.7^{\mathrm{ab}}$ & $7.2^{\mathrm{ab}}$ & $7.8^{\mathrm{b}}$ & 0.32 & 0.04 \\
\hline
\end{tabular}

${ }^{a b c}$ Different literals in the same row mean statistical significant effect. $\mathrm{PM}=$ progressive motility; $\mathrm{CS}=$ capacitated spermatozoa; NCS = non-capacitated spermatozoa; REA = reacting spermatozoa.

Table 2. Effect of incubation time with different chemical agents on progressive motility and functional state of the caprine spermatozoa membrane.

\begin{tabular}{|c|c|c|c|c|c|c|}
\hline \multirow[t]{2}{*}{ Variable $(\%)$} & \multicolumn{4}{|c|}{ Incubation time (min) } & \multirow[t]{2}{*}{ SE } & \multirow[t]{2}{*}{ P-value } \\
\hline & 60 & 120 & 180 & 240 & & \\
\hline PM & $57.4^{\mathrm{a}}$ & $49.6^{\mathrm{b}}$ & $42.7^{\mathrm{c}}$ & $40.1^{\mathrm{c}}$ & 1.73 & 0.0001 \\
\hline $\mathrm{CS}$ & $52.9^{\mathrm{a}}$ & $56.3^{\mathrm{ab}}$ & $60.1^{\mathrm{bc}}$ & $63.3^{\mathrm{c}}$ & 1.71 & 0.002 \\
\hline NCS & $40.1^{\mathrm{a}}$ & $35.9 \mathrm{a}^{\mathrm{b}}$ & $31.4^{b c}$ & $27.9^{c}$ & 1.65 & 0.0001 \\
\hline REA & $6.9^{\mathrm{a}}$ & $7.8^{\mathrm{a}}$ & $8.4^{\mathrm{a}}$ & $8.7^{\mathrm{a}}$ & 0.53 & 0.08 \\
\hline
\end{tabular}

${ }^{\mathrm{abc}}$ Different literals in the same row mean statistical significant effect. PM $=$ progressive motility; $\mathrm{CS}=$ capacitated spermatozoa; NCS = non-capacitated spermatozoa; $\mathrm{REA}=$ reacting spermatozoa.
Table 3. Effect of incubation day with different chemical agents on progressive motility and functional state of the caprine spermatozoa membrane.

\begin{tabular}{cccccc}
\hline \multicolumn{7}{c}{ Evaluation day } \\
\hline Variable (\%) & $1(0 \mathrm{~h})$ & $2(24 \mathrm{~h})$ & $3(48 \mathrm{~h})$ & $\mathrm{SE}$ & P-value \\
\hline PM & $55.6^{\mathrm{a}}$ & $49.2^{\mathrm{b}}$ & $37.7^{\mathrm{c}}$ & 1.45 & 0.0001 \\
$\mathrm{CS}$ & $56.1^{\mathrm{a}}$ & $55.3^{\mathrm{a}}$ & $62.3^{\mathrm{b}}$ & 0.82 & 0.002 \\
NCS & $37.2^{\mathrm{a}}$ & $35.8^{\mathrm{a}}$ & $28.4^{\mathrm{b}}$ & 0.95 & 0.0001 \\
REA & $5.8^{\mathrm{a}}$ & $8.1^{\mathrm{b}}$ & $9.3^{\mathrm{b}}$ & 0.28 & 0.0001 \\
\hline
\end{tabular}

${ }^{a b c}$ Different letters in the same row mean statistical significant effect. PM $=$ progressive motility; CS = capacitated spermatozoa; NCS = non-capacitated spermatozoa; REA = reacting spermatozoa.

\section{Discusion}

Capacitation process is a prerequisite step for sperm to bind to the zona pellucida, it experiment acrosomic reaction in response to natural agonistics and express hypermotility, a special movement that allow spermatozoa to move in the viscose fluid of the oviduct and get into the zona pellucida [28].

The results of this study indicate that caprine semen diluted in Triladyl could be preserve at $15^{\circ} \mathrm{C}$ until $48 \mathrm{hs}$ maintaining an acceptable motility $(\mathrm{P}>0.0001)$. Probably the presence of lipoproteins of egg yolk and milk may not be required because the extender per se, compose of TRIS, sugar, glycerol and citric acid, is capable of providing the nutrients that the spermatozoa need for its metabolism. It also gives protection against $\mathrm{pH}$ variation [26], an adequate osmotic pressure for the spermatozoa, and avoidsdehydration damage through the stabilization of the lipid bilayer. In vivo the $\mathrm{pH}$ of luminal fluid in the reproductive tract has effects on the whole process of reproduction, including spermatogenesis, sperm capacitation, fertilization, and early stage embryo development. The epithelia lining along the reproductive tract wall of both males and females actively perform considerable transepithelial transport of acid-base equivalents to tightly control the $\mathrm{pH}$ of luminal fluid milieu along the entire reproductive tract [29]. Because sugars (sucrose, raffinose, trehalose and lactose) are non-penetrating cryoprotectors of high molecular weight they are useful when applied at high cooling speeds, because the cryoprotector action is associated with its dehydrate activity and its specific interaction with the phopholipid membrane [30]. In this context, the type and sugar concentration used can modify not only the sperm motility but also the viability and acrosomal integrity [31]. In general the monosaccharides in addition to act as cryoprotector play other functions. They provide a source of energy for the spermatic cell and maintain the osmotic pressure [32].

The glycerol has been used as a penetrating cryoprotector agent since its discovery by Polge et al. [33]. It has 
been show that their presences in the extenders reduces damage in the spermatozoa, because it avoids the build of intracellular crystal ice, as well as the excessive dehydration caused by the slow cooling [34], and improve fertility [8]. The differences between studies respect to the use of glycerol, are due to alterations in the organization and viscosity of the cytoplasm of the spermatozoa, to the permeability and stability of the membrane, and alteration of the protein and phospholipids organization [35]. However, the previous could be due to many factors such as glycerol concentration, the use of different diluents, different cryopreservation protocols, and the use of other cryoprotectors; as well as the different criteria and methods used to evaluate sperm quality [36].

Sugar and glycerol act in a way that their hydrogen bind to the polar group of the head of the membrane lipids, which have the ability to replace the water molecules normally found in the polar groups, which help to stabilize the membrane during the temperature transition [8].

On the other hand, the results of CS (56.1\%) and PM $(55.6 \%)$ here obtained indicated that the spermatzoa can be conserved during one day only, this is due to that citric acid and sugar compounds provide a source of energy enough for the sperm metabolism and to increase motility [37] but can decrease viability. Previous studies indicate that the use of Triladyl can provide substrates such as citric acid, which through a series of chemical reactions favor sperm motility due to an increase of ATP production [38]. Spermatozoa require a permanent production of ATPs in order to maintain the cell structure, the composition of intracellular ions and motility. It has been hypothezised that composition of ions participate in the capacitation process [39].

The decreasing effect of HEP on PM and the increas ing effect of CAF on CS agree with the results of Zhou et al. [40], who evaluating the effect of heparin in fresh semen during caprine spermatic capacitation by $120 \mathrm{~min}$ observed a significant reduction of motility and membrane integrity. El Gaafary et al. [41] using CAF obtained acceptable results of sperm motility of fresh bovine semen during $1 \mathrm{~h}$; however, motility decreased as incubation time increased (up to $6 \mathrm{hs}$ ).

Previous research suggested that the reduction of the motility of in vitro capacitated spermatozoa treated with heparin or caffeine may be due to reduction of the glycosylable substrates like glucose and/or fructose, and also to a reduction in the availability of pyruvate and lactate, substrates that during the cell metabolism are primordial to produce ATPs [42]; which make difficult its conservation and use for longer times.

Respect to the medium known as synthetic oviduct fluid (SOF) which composition is based in the biochemical analysis of ovine oviduct fluid plus HEPES and polyvinyl alcohol (PVA). The incubation results with the SOF medium showed a greater PM than for CAF and HEP but the capacitation percentages was similar. The mechanism by which the motility vary has not been established. However, it is known that motility is particularly dependent of the mitochondrial function [43]. Mitochondrias are strategically distributed around the midpiece of the spermatozoa to provide energy to dynein that propel the microtubules. The mitochrondia provides the main source of oxidative energy throughout the production of ATPs via the electrons transport chain. In the other hand, the response to the capacitation could be due to the fact that the medium is a source of intracellular ions $\left(\mathrm{NaCl}, \mathrm{KCl}, \mathrm{KH}_{2} \mathrm{PO}_{4}, \mathrm{MgCl}_{2}, \mathrm{NaHCO}_{3}, \mathrm{CaCl}_{2}\right)$ pyruvate and lactate, that cause changes in the properties of the plasmatic membrane, particularly of the ionic conductance which has been shown to be powerful regulator of the metabolism and consequently of capacitation and sperm motility [44]. Also, it is known that bicarbonate plays an important role in the capacitation and fertilization processes both in vivo and in vitro, because it increases the distabilization of the lipid membrane [45], and regulates and stimulates the adenylcyclase activity that increases the concentration of AMPc and speed up the A1 cyanase protein (PKA1), which phosphorylate some proteins [46]. In the other hand, Huo et al. [47] made reference to the fact that the elimination of the seminal plasma by centrifugation and sperm dilution could cause destabilization of the spermatic membrane. Therefore the hydrophobic an adjustment among membranes of the proteins and the "lipidic rafs" cause small changes in the membrane thickness [48] and protein interactions with lipidic rafs. This may allow the exteriorization of receptors of the ionic channels that participate in the activation of the mechanism of calcium transduction flux, AMPc synthesis, and protein phosphorylation diphosphorylation [49].

\section{Conclusion}

In summary, TRY without egg yolk and milk could be an option for refrigerating caprine sperm and flexible option to use in caprine AI programs. The use of SOF medium and TRY extender as chemical agents maintained an acceptable motility and sperm capacitation for longer time compared with HEP or CAF. However, further FIV test are required to determine the fecundate capacity of the spermatozoa.

\section{REFERENCES}

[1] H. Baldassarre and C. N. Karatzas, "Advanced Assisted Reproduction Technologies (ART) in Goats," Animal Reproduction Science, Vol. 82, 2004, pp. 255-266. doi:10.1016/j.anireprosci.2004.04.027 
[2] G. Evans and W. M. Maxwell, "Inseminación Artificial en Ovejas y Cabras," Acribia, Zaragoza, España, 1990, pp. 204.

[3] R. D. Martínez Rojero, I. Hernández Javier, H. Hernández Hernández, A. C. Michel Aceves and J. Valencia Méndez, "Inseminación Articial Intrauterina en Cabras Criollas con Semen Refrigerado," Agrociencia, Vol. 40, No. 1, 2006, pp. 71-76.

[4] J. Yániz, J. L. Martí, M. A. Silvestre, J. Folch, P. Santolaria, J. L. Alabart and F. López-Gatius, "Effects of Solid Storage of Sheep Spermatozoa at $15^{\circ} \mathrm{C}$ on the Survival and Penetrating Capacity," Theriogenology, Vol. 64, No. 8, 2005, pp. 1844-1851.

[5] I. Salvador, J. Yániz, M. P. Viudes-de-Castro, E. A. Gómez and M. A. Silveste, "Effect of Solid Stage on Caprine Semen Conservation at $5^{\circ} \mathrm{C}$," Theriogenology, Vol. 66, No. 4, 2006, pp. 974-981.

doi:10.1016/j.theriogenology.2006.02.042

[6] J. R. Baquero Parrado, E. A. Pardo Romero and C. P. E. Cruz, "Evaluación de dos Diluyentes Para la Conservación de Semen Canino Bajo Condiciones de RefrigeraciÓN: Efectos del Tiempo de RefrigeraciÓN, Grado de Dilución Y de la ConcentraciÓN de Fructuosa," Orinoquia, Vol. 8, No. 1, 2004, pp. 26-33.

[7] A. Santiani, "Criopreservación de Semen Ovino: Efecto de la Adición de Antioxidantes al Diluyente," Tesis de Maestría en Ciencias Facultad de Medicina, Universidad de La Frontera, Temuco Chile, 2003.

[8] R. Vishwanath and P. Shannon, "Storage of Bovine Semen in Liquid and Frozen State," Animal Reproduction Science, Vol. 62, No. 1-3, 2000, pp. 23-53. doi:10.1016/S0378-4320(00)00153-6

[9] E. M. Aboagla and T. Terada, "Effects of Egg Yolk during the Freezing Step of Cryopreservation on the Viability of Goat Spermatozoa," Theriogenology, Vol. 62, No. 6, 2004, pp. 1160-1172.

doi:10.1016/j.theriogenology.2004.01.013

[10] P. H. Purdy, "A Review on Goat Sperm Cryopreservation," Small Ruminant Research, Vol. 63, No. 3, 2006, pp. 215-225. doi:10.1016/j.smallrumres.2005.02.015

[11] T. Vera, "Evaluación Sobre La Viabilidad y Fertilidad de Espermatozoides Caprinos Congelados con Diluyente sin Proteína Animal y el Agregado de Plasma Seminal pos Descongelado," 2006.

http://www.inta.gov.ar/balcarce/ResumenesPG/PGPA200 6/ResumenTOMASVERA

[12] I. Ashrafi, H. Kohram, H. Naijian, M. Bahreini and H. Mirzakhani, "Effect of Controlled and Uncontrolledcoolingrate on Motility Parameters of Cryopreserved Ram Spermatozoa," African Journal of Biotechnology, Vol. 10, No. 44, 2011, pp. 8965-8969.

[13] R. D. Salgado, C. C. Rugeles and P. Jaime Álvarez, "Efecto de La Heparina y de La Concentración Espermática Sobre el Porcentaje de Fertilización de Oocitos Bovinos in Vitro," Revista Colombiana de Ciencias Pecuarias, Vol. 2, No. 18, 2005, pp. 122-126.

[14] A. M. Salicioni, M. D. Platt, E. V. Wertheimer, E. Arcelay, A. Allaire, J. Sosnik and P. E. Visconti, "Signalling Pathways Involved in Sperm Capacitation," Society of
Reproduction and Fertility Supplement, Vol. 65, 2007, pp. 245-259.

[15] L. R. Fraser, L. R. Abeydeera and K. Niwa, "Ca ${ }^{2+}$-Regulating Mechanisms that Modulate Bull Sperm Capacitation and Acrosomal Exocytosis as Determined by Clortetracycline Analysis," Molecular Reproduction and Development, Vol. 40, No. 2, 1995, pp. 233-241. doi:10.1002/mrd.1080400213

[16] A. S. Bergqvist, J. Ballester, A. Johannisson, M. Hernandez, N. Lundeheim and H. Rodríguez-Martínez, "In Vitro Capacitation of Bull Spermatozoa by Oviductal Fluid and Its Components," Zygote, Vol. 14, No. 3, 2006, pp. 259-273. doi:10.1017/S0967199406003777

[17] G. Killian, "Physiology and Endocrinology Symposium: Evidence that Oviduct Secretions Influence Sperm Function: A Retrospective View for Livestock," Journal of Animal Science, Vol. 89, No. 5, 2011, pp. 1315-1322. doi:10.2527/jas.2010-3349

[18] P. I. Caballero, "Estudio del Plasma Seminal y La Espermadhesina PSP-I/PSP-II Sobre La Funcionalidad de los Espermatozoides de Verraco," Thesis doctoral, Universidad de Murcia, España, 2007.

[19] M. Olivera, T. Ruíz, A. Tarazona and C. Giraldo, "El Espermatozoide, Desde La Eyaculación Hasta La Fertilización," Revista Colombiana de Ciencias Pecuarias, Vol. 19, No. 4, 2006, pp. 426-436.

[20] R. Lösel, A. Dorn-Beineke, E. Falkenstein, M. Wehling and M. Feuring, "Porcine Spermatozoa Contain More than One Membrane Progesterone Receptor," International Journal of Biochemistry \& Cell Biology, Vol. 36, No. 8, 2004, pp. 1532-1554. doi:10.1016/j.biocel.2004.01.003

[21] M. M. Castañon, "Glicosaminoglicanos en Hemostasia: AccióN del DermatÁN Sulfato Sobre el Sistema FibrinolÍTico," Acta Bioquímica Clínica Latinoamericana, Vol. 42, No. 4, 2008, pp. 509-528.

[22] I. Therien, G. Bleau and P. Manjunath, "Phosphatidylcholine-Biding Proteins of Bovine Seminal Plasma Modulate Capacitation of Spermatozoa by Heparin," Biology of Reproduction, Vol. 52, No. 6, 1995, pp. 1372-1379. doi:10.1095/biolreprod52.6.1372

[23] A. Chamberland, V. Fournier, S. Tardif, Ma. Sirard, R. Sullivan and J. L. Bailey, "The Effect of Heparin on Motility Parameters and Protein Phosphorylation during Bovine Sperm Capacitation," Theriogenology, Vol. 55, No. 3, 2011, pp. 823-835. doi:10.1016/S0093-691X(01)00446-0

[24] R. J. Pereira, R. K. Tuli, S. Wallenhorst and W. Holtz, "The Effect of Heparin, Caffeine and Calcium Ionophore A 23187 on in Vitro Induction of the Acrosome Reaction in Frozen-Thawed Bovine and Caprine Spermatozoa," Theriogenology, Vol. 54, No. 2, 2000, pp. 185-192. doi:10.1016/S0093-691X(00)00340-X

[25] M. J. Vila Cantariño, J. Soria Bartolomé, A. Aguilera Bazán, S. Gonzáles Gill and V. López Rodas, "Utilización de Técnicas de Swim-Up en La Mejora del Semen de Ganado Vacuno," Archivos de Zootecnia, Vol. 42, No. 158, 1993, pp. 229-236.

[26] P. Guérin, M. Ferrer, A. Fontbonne, L. Bénigni, M. Jac- 
quet and Y. Ménézo, "In Vitro Capacitation of Dog Spermatozoa as Assessed by Chlortetracycline Staining," The-riogenology, Vol. 52, No. 4, 1999, pp. 617-628. doi:10.1016/S0093-691X(99)00157-0

[27] Statistical Analysis System, "Institute Inc. SAS/STAT User's Guide," 6.03th Edition, SAS Institute, Cary, 1998.

[28] Y. Liu, D. K. Wang and L. M. Chen, "The Physiology of Bicarbonate Transporters in Mammalian Reproduction," Biology of Reproduction, Vol. 86, No. 4, 2012.

[29] A. T. Reid, K. Redgrove, R. J. Aitken and B. Nixon, "Cellular Mechanisms Regulating Sperm-Zona Pellucida Interaction," Asian Journal of Andrology, Vol. 13, No. 1, 2011, pp. 88-96. doi:10.1038/aja.2010.74

[30] E. G. Aisen, V. H. Medina and A. Venturino, "Cryopreservation and Post-Thawed Fertility of Ram Semen Frozen in Different Trehalose Concentrations," Theriogenology, Vol. 57, No. 7, 2002, pp. 1801-1808. doi:10.1016/S0093-691X(02)00653-2

[31] T. Rigau, M. Rivera, M. J. Palomo, J. M. FernándezNovell, T. Mogas, J. Ballester, A. Peña, P. J. Otaequi, J. J. Guinovart and J. E. Rodríguez-Gil, "Differential Effects of Glucose and Fructose on Hexose Metabolism in Dog Spermatozoa," Reproduction, Vol. 123, No. 4, 2002, pp. 579-591. doi:10.1530/rep.0.1230579

[32] C. Yildis, A. Kaya, M. Aksoy and T. Tekeli, "Influence of Sugar Supplementation of the Extender on Motility, Viability and Acrosomal Integrity of Dog Spermatozoa during Freezing," Theriogenology, Vol. 54, No. 4, 2000, pp. 579-585. doi:10.1016/S0093-691X(00)00373-3

[33] C. Polge, A. U. Smith and A. S. Parkes, "Revival of Spermatozoa after Vitrification and Dehydration at Low Temperatures," Nature, Vol. 164, No. 4172, 1949, p. 666. doi:10.1038/164666a0

[34] C. M. Medeiros, F. Forell, A. T. Oliveira and J. L. Rodríguez, "Current Status of Sperm Cryopreservation: Why Isn't It Better?" Theriogenology, Vol. 57, No. 1, 2002, pp. 327344. doi:10.1016/S0093-691X(01)00674-4

[35] A. Swelum, H. A. Mansour, A. A. Elsayed and H. A. Amer, "Comparing Ethylene Glycol with Glycerol for Cryopreservation of Buffalo Bull Semen in Egg-Yolk Containing Extender," Theriogenology, Vol. 5, No. 76, 2011, pp. 833-842.

[36] E. Mocé, E. Blanch, C. Tomás and J. K. Graham, "Use of Colesterol in Sperm Cryopreservation: Present Moment and Perspectives to Future," Reproduction in Domestic Animals, Vol. 45, No. S2, 2010, pp. 57-66.

[37] E. T. Donnelly, S. E. Lewis, J. A. McNally and W. Thompson, "In Vitro Fertilization and Pregnancy Rates: The Influence of Sperm Motility and Morphology on IVF Outcome," Fertility and Sterility, Vol. 70, No. 2, 1998, pp. 305-314. doi:10.1016/S0015-0282(98)00146-0

[38] K. Alberti, "Congelacao de Semen Bovino: Novos Enfoques em Meios Diluentes," Programa de Pós graduacao em Medicina Veterinária. Monografía apresentada a Faculdade de Medicina Veterinária e Zootecnia da Universidade Estadual Paulista (Unesp), Campus de Botucatu, 2004.

[39] M. D. A. Arvelo, "Estudio del Metabolismo Energético de los Espermatozoides Porcinos y su Repercusión en el Diseño de Diluyentes Optimizados Para La Conservación de Semen Refrigerado," Thesis Doctoral, Universidad Autónoma de Barcelona, España, 2005.

[40] J. B. Zhou, Y. G. Wu, L. Q. Liu, M. J. Luo, Z. L. Chang, X. W. Tan, N. Liu and J. H. Tan, "Studies on in Vitro Capacitation of Goat Spermatozoa by Heparin Treatment," Shen Wu Gong Cheng Xue Bao, Vol. 20, No. 2, 2004, pp. 252-256.

[41] M. N. El-Gaafary, A. H. Daader and A. Ziedan, "Effects of Caffeine on Bull Semen Quality and Sperm Penetration into Cervical Mucus," Animal Reproduction Science, Vol. 23, No. 1, 1990, pp. 13-19.

doi:10.1016/0378-4320(90)90011-4

[42] R. F. Fernández, G. Y. Gutiérrez, N. N. E. Gómez and P. J. E. Hernández, "Motilidad y Sobrevivencia Espermática in vitro Con La Utilización De Pirofosfato De Tiamina En Semen Caprino," Revista de Salud Animal, Vol. 25, No. 1, 2003, pp. 34-38

[43] S. H. Kao, H. T. Chao and Y. H. Wein, "Multiple Deletions of Mitochondrial DNA Are Associated with the Decline of Motility and Fertility of Human Spermatozoa," Molecular Human Reproduction, Vol. 4, No. 7, 1998, pp. 657-666. doi:10.1093/molehr/4.7.657

[44] J. L. Gatti, C. Chevrier, M. Paquignon and J. L. Dacheux, "External Ionic Conditions Internal $\mathrm{Ph}$ and Motility of Ram and Boar Spermatozoa," Journal Reproduction and Fertility, Vol. 98, No. 2, 1993, pp. 439-449. doi:10.1530/jrf.0.0980439

[45] B. M. Gadella and R. A. Harrison, "The Capacitating Agen Bicarbonate Induces Protein Kinase A-Dependent Changes in Phospholipid Trasbilayer Behavior in the Sperm Plasma Membrane," Development, Vol. 127, No. 11, 2000, pp. 2407-2420

[46] M. L. Vadnais, H. L. Galantino-Homer and G. C. Althouse, "Current Concepts of Molecular Events during Bovine and Porcine Spermatozoa Capacitation," Archives of Andrology, Vol. 53, No. 3, 2007, pp. 109-123. doi: $10.1080 / 01485010701329386$

[47] L. J. Huo, X. H. Ma and Z. M. Yang, “Assessment of Sperm Viability Mitochondrial Activity, Capacitation and Acrosome Intactness in Extended Boar Semen during Long-Term Storage," Theriogenology, Vol. 58, No. 7, 2002, pp. 1349-1360. doi:10.1016/S0093-691X(02)00953-6

[48] J. A. Killian, "Hydrophobic Mismatch between Proteins and Lipids in Membranes," Biochimica et Biophysica Acta, Vol. 1376, No. 3, 1998, pp. 401-415. doi:10.1016/S0304-4157(98)00017-3

[49] S. B. Sleight, P. V. Miranda, N. W. Plaskett, B. Maier, J. Lysiak, H. Scrable, C. J. Herr and P. E. Visconti, "Isolation and Proteomic Analysis of Mouse Sperm DetergentResistant Membrane Fractions: Evidence for Dissociation of Lipid Rafts during Capacitation," Biology of Reproduction, Vol. 73, No. 4, 2005, pp. 721-729. doi:10.1095/biolreprod.105.041533 